\title{
A global perspective on denudation data, primarily specific sediment yield in mountainous regions
}

\author{
Olav Slaymaker $\oplus$
}

Department of Geography, University of British Columbia, Vancouver, Canada, olav.slaymaker@ubc.ca

\begin{abstract}
A brief review of the evolution of denudation research since the 1960s is followed by a review of specific sediment yield variability in mountainous regions of the world as a function of spatial scale, relief, glaciation, lithology and disturbance type and location within the basin. A general model of scalar relations of suspended sediment yield for Canadian regions warns against comparing data from basins with areas ranging over several orders of magnitude. A regional summary of specific sediment yield in mountainous British Columbia confirms that in basins $<1 \mathrm{~km}^{2}$ and $>30,000 \mathrm{~km}^{2}$ specific sediment yield decreases with basin size whereas in basins of intermediate size (between $1 \mathrm{~km}^{2}$ and $30,000 \mathrm{~km}^{2}$ ) specific sediment yield increases with basin size. This effect is interpreted in terms of three distinct process zones in every mountain basin. These zones can be characterized as a) generally degrading hillslope zones, b) generally aggrading footslopes and valley sides, and c) channelized flows on valley floors demonstrating either net aggradation or degradation. These are identifiable repeating elements in such landscapes. Suspended sediment yield data from mountainous regions around the world are considered in light of the British Columbia model. Some support for the model is found where basins are stratified according to scale, relief, lithology, disturbance types, and location within each basin. Disturbance types include the presence of glaciers, land use activities of various kinds, such as increasing population pressure in the intertropical montane zone, changing population distribution and associated economic activities in the temperate montane zone, and potentially hydroclimate change.
\end{abstract}

Key words: denudation, scale, relief, lithology, disturbance

\section{Introduction}

The purpose of this study is to note some improvements in understanding of the factors that govern denudation over the past five decades, primarily through intensive field work, sampling design, conceptual modelling and analysis of surface erosion and fluvial sediment flux. Slaymaker (1968, 1972) advocated greater attention to questions of precision, accuracy, sampling design and standardization in procedures for collecting and reporting data on patterns of surficial erosion. His study remains unique with respect to a hierarchical sampling design and

Fig. 1. Schematic diagram of sampling units used to determine patterns of subaerial erosion in Mid-Wales (Slaymaker 1968, 1972)

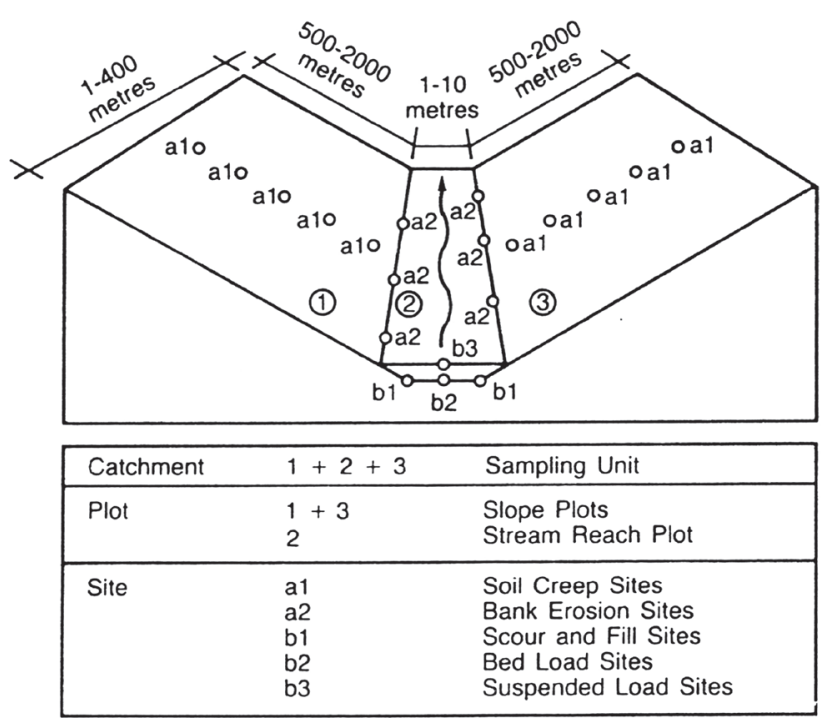




\section{Upper Wye and Elan}

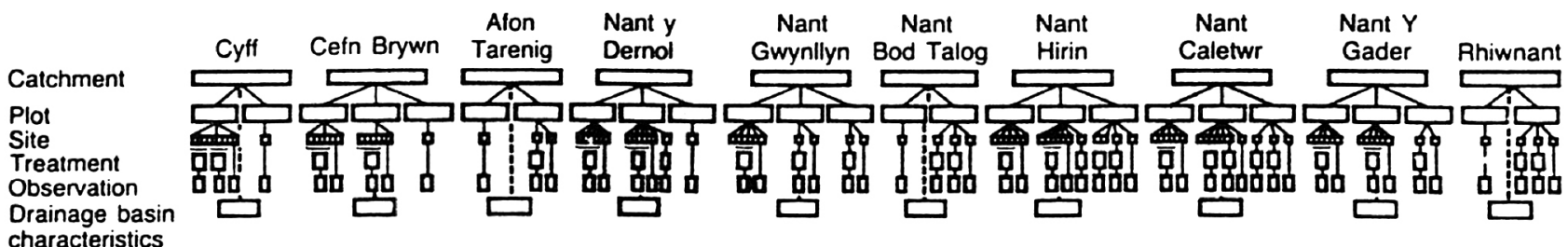

Fig. 2. Hierarchical design of field experiment in mid-Wales including ten drainage basins, twenty slope/stream reach plots and two hundred sampling sites (Slaymaker 1972)

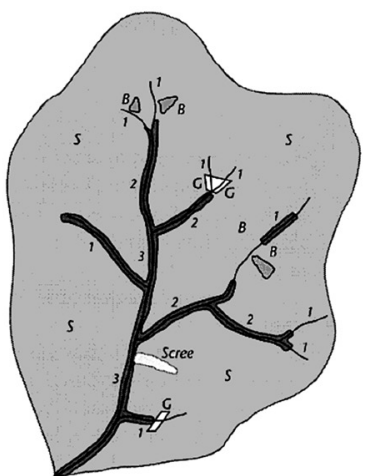

A Holocene time scale

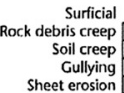

Surficial

Soil creep
Gullying

cete erosion

Overall rate of denudation

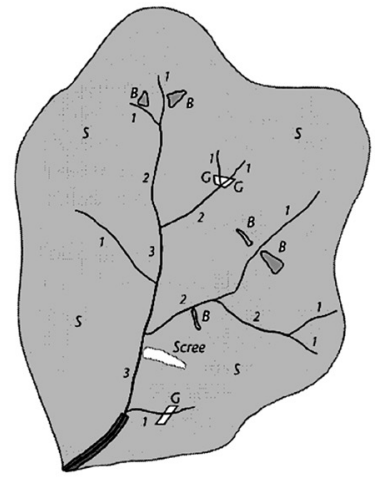

B Geological time scale

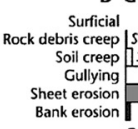
Surficial Iscre

Soil creep 75

heet erosion

Overall rate of denudation: $9 \mathrm{~mm} / 1,000 \mathrm{yr}$

Fig. 3. General model of landscape evolution in mid-Wales A - over Holocene time scale, B - over geological time scale (Slaymaker 1972)

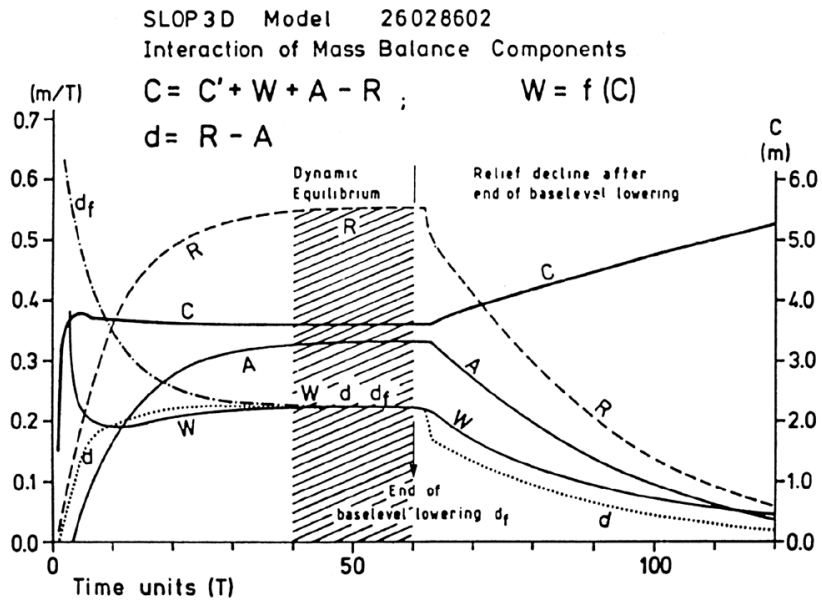

Fig 4. Interaction of the mass budget components at a slope point through time (Ahnert 1970)

C - regolith thickness, C' - previous regolith thickness, W weathering rate, $\mathrm{A}$ - rate of waste arrival from upslope, $\mathrm{R}$ - rate of waste removal in the downslope direction, $\mathrm{d}$ - local denudation rate, $d_{f}-$ rate of lowering of the slope foot (local baselevel) (Ahnert 1987)

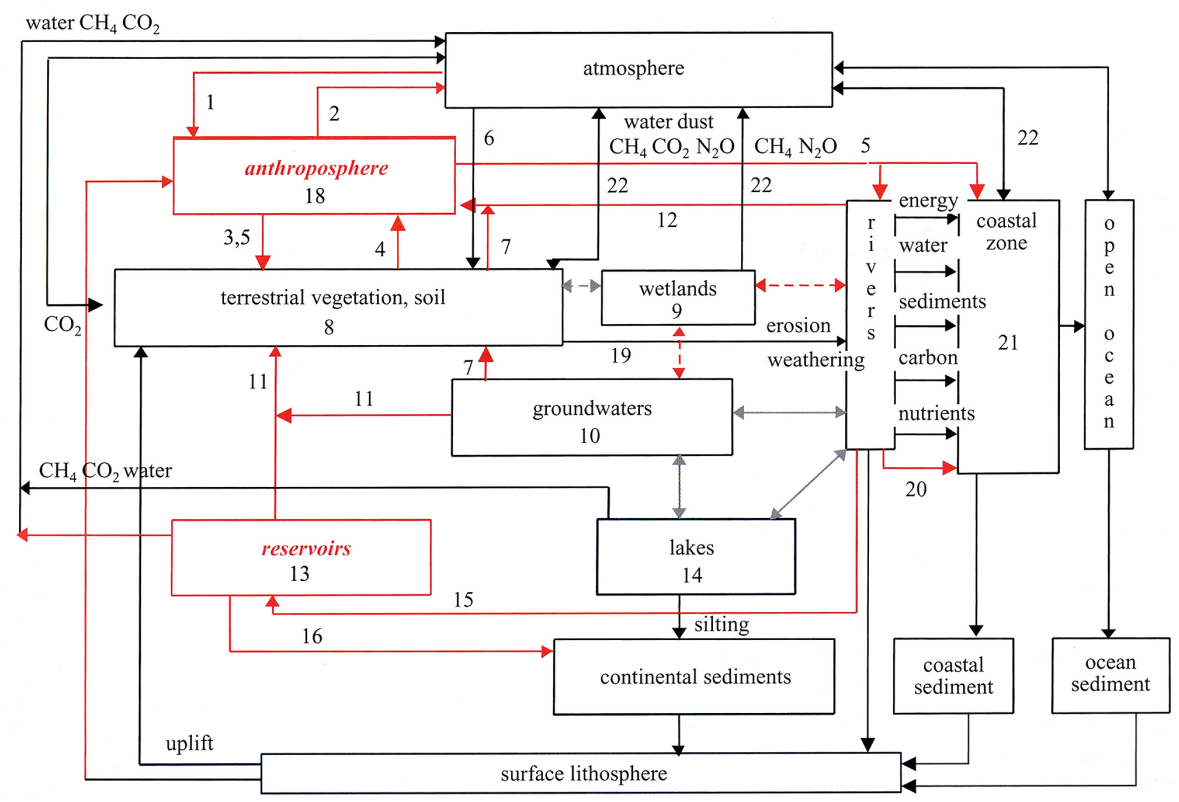

Fig. 5. Pathways of major elements from land to ocean: storage areas in rectangles and interactions between sediments and dissolved solids at continental aquatic system scale (Meybeck 2003)

Natural fluxes and pathways of material in black, major impacts of human activities in red 

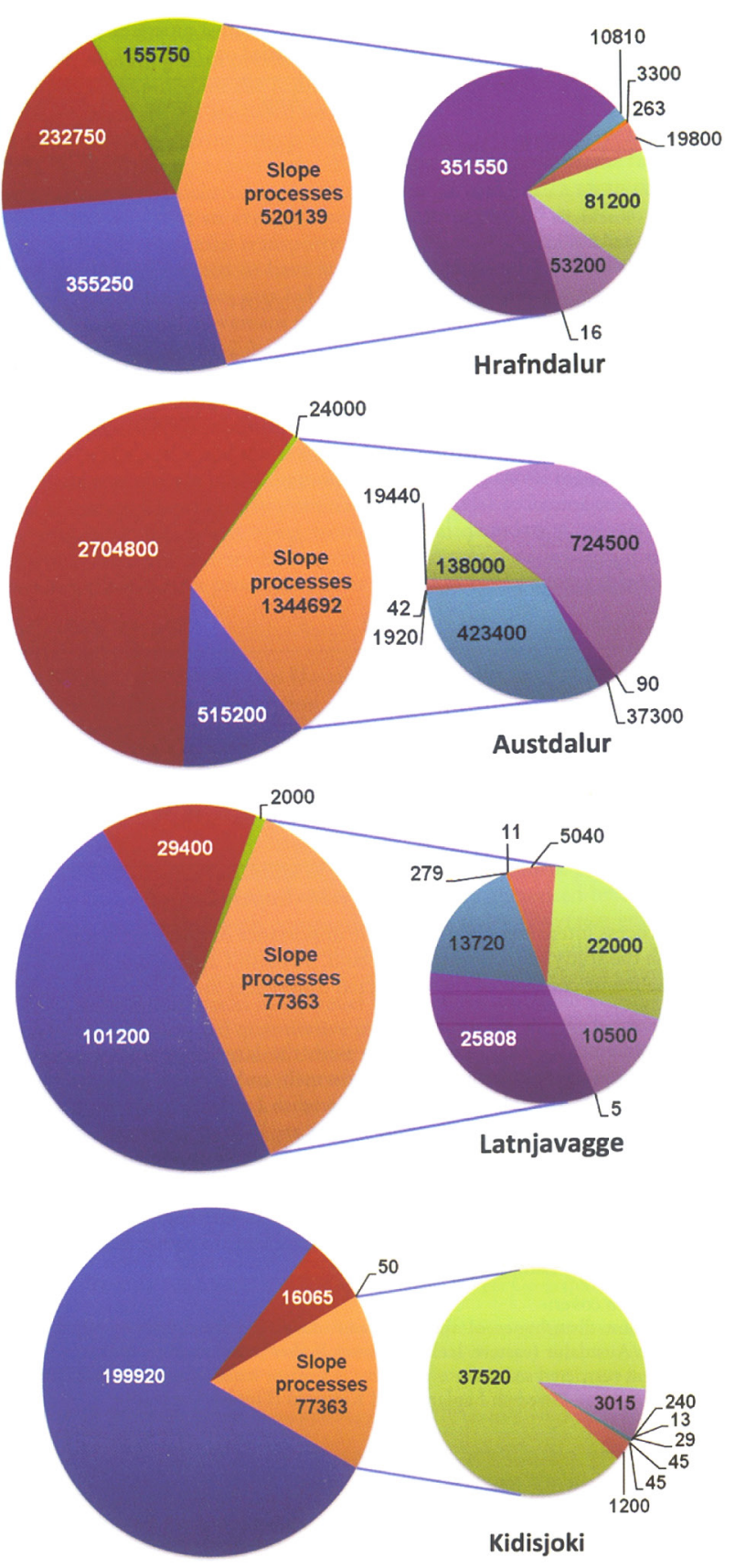

Mass transfers [ $\left.\mathrm{t} \mathrm{m} \mathrm{yr}^{-1}\right]$

Stream work

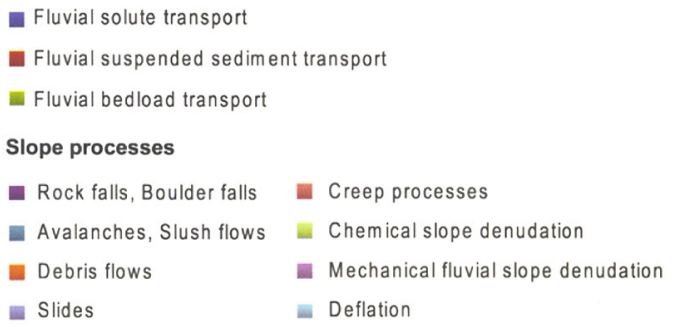

Fig. 6. The absolute and relative importance of the different denudative processes in sub-arctic oceanic eastern Iceland (Hrafndalur and Austdalur), arctic-oceanic Swedish Lapland (Latnjavagge) and sub-arctic continental Finnish Lapland (Kidisjoki) (Beylich 2011) defining fundamental sampling units for integrated surface erosion and fluvial sediment flux (Figs 1, 2).

The weakness of the study lay in its dependence on temporally discontinuous measurements of sediment movement and the labour intensiveness of the field procedures. The result of the study was to establish the importance of fluvial bank erosion as the dominant denudational process in mid-Wales during the Holocene epoch (Fig. 3).

At the same time, Ahnert (1970) was exploring the potential of conceptual modelling of the mass budget components of drainage basins through time. His work transformed our thinking about denudation as it showed the range of possible interactions between regolith thickness, weathering rate and waste removal in the downslope direction (Ahnert 1987, Fig. 4).

Later, Meybeck $(1979,1982)$ asked the previously neglected question What is the role of dissolved solids and nutrients in the overall geochemical mass balance and sediment mass budget? (Fig. 5). His flow diagram of the interactions between the various processes driving the global geochemical mass balance of drainage basins drew attention not only to the importance of dissolved solids and nutrient pathways on their way to the open ocean but also incorporated the anthroposphere into the mass balance (Meybeck 2003).

Finally, in this overly brief overview, the work of Beylich (2011, Fig. 6) provides a comprehensive breakdown of all clastic and solute sources in an integrated slope and channel system framework (e.g. Beylich 2000, 2011). The absolute and relative importance of the different denudative processes in sub-arctic oceanic eastern Iceland, arctic-oceanic Swedish Lapland, and sub-arctic continental Finnish Lapland were determined for the first time.

\section{Mountains and mountain typology}

As a framework for understanding both sediment yield and human occupance, the physiographic variation of mountains is important. A typology based on elevation bands $>500 \mathrm{~m}$ a.s.l. and relief $>60 \mathrm{~m} \mathrm{~km}^{-1}$ is proposed as follows:

- high and very high mountains (>2,500 m a.s.l.) covering c. 6 million $\mathrm{km}^{2}$ and containing c. $12 \%$ of mountain peoples,

- low and mid-elevation mountains (500-2,500 m a.s.l.), covering c. 17 million $\mathrm{km}^{2}$ and containing c. $88 \%$ of mountain peoples.

The first category of mountains is widely distributed not only in the Andes and the Karakoram-Himalayan mountains but also includes the North American Cordillera, the European Alps, the Pamirs, the Tien Shan and the Siberian ranges inter al. The high 


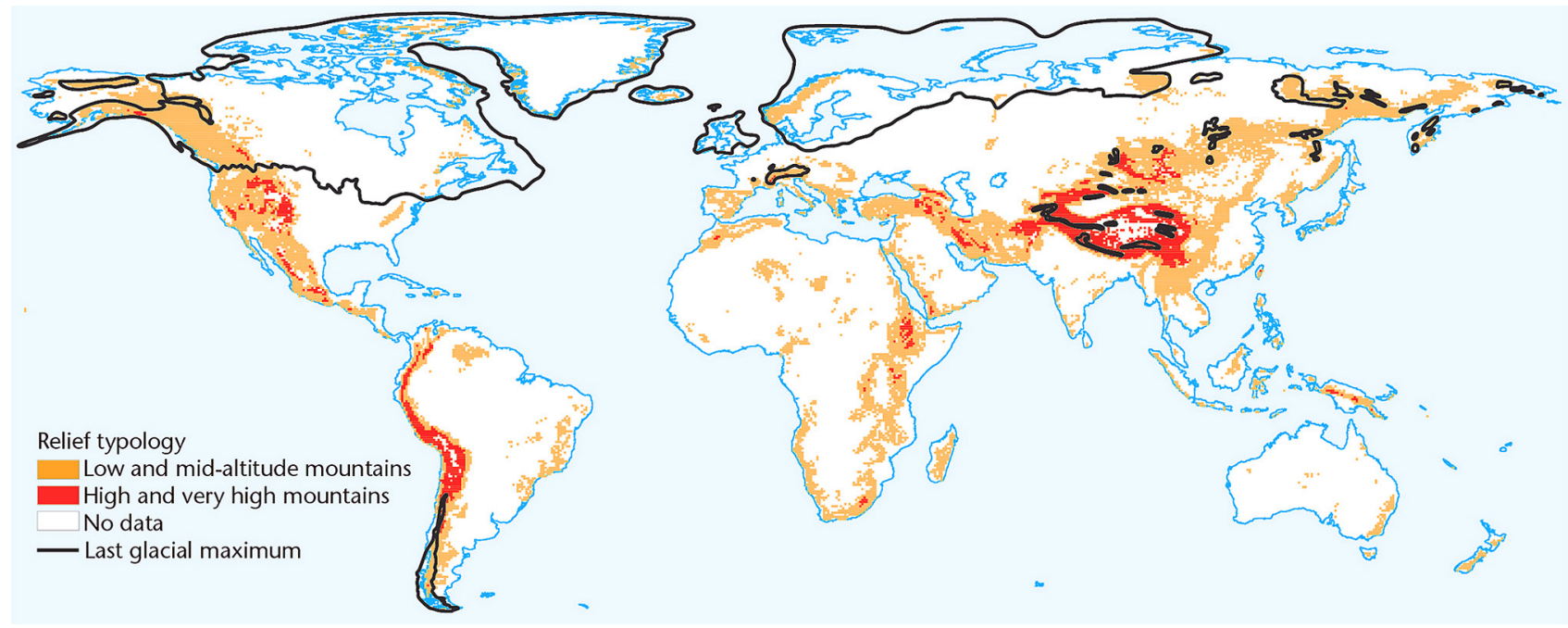

Fig. 7. Map showing distribution of low and intermediate and high and very high mountains (after Slaymaker, Embleton-Hamann 2009) with the extent of late Pleistocene glaciation overprinted; Antarctica is not represented (Church, Slaymaker 2016)

and very high mountain zones can be considered the most prolific source of mountain sediments undisturbed by human settlement.

The second category of mountains occurs as foothills around major mountain massifs such as the Cordilleras and the Himalayas and as discrete mountain chains in the interior and margins of the passive tectonic plates. The low and mid-elevation mountain zones can be considered both a natural and disturbed source of mountain sediments and a transportation zone for evacuating mountain sediments (Slaymaker, Embleton-Hamann 2009).

Mountains may also be categorized according to the dominant hydroclimate. Glacierized mountains are subject to extreme rates of physical weathering and erosion due to the direct scouring and sediment transporting effects of glacier ice and to freeze and thaw activity. Seasonal meltwater redistributes sediments beyond glacier margins. The glaciated mountains surrounding the glacier-covered areas produce a signal that is influenced by the presence or absence of a sedimentologically active paraglacial environment (Ballantyne 2002). Unglaciated mountains show the first order effects of relief, hydroclimate, geology and land use. The distinction between glacierized, glaciated and unglaciated mountains is, then, of first order importance.

Furthermore geology plays a fundamental role. Recently deformed sedimentary rocks are notoriously erodible, in contrast to, for example, intrusive igneous rock. While the former constitute a significant body in recently uplifted orogens (mostly high to very high mountains) the latter are more frequently exposed as the remaining core of older mountains now having low to mid-elevation. The extrusive igneous rocks of volcanic complexes are prone to weathering, while metamorphic rocks exhibit a range of weathering susceptibility. Few generalizations about erodibility are possible though there is some correlation between highly weatherable types and the highest mountains.

Finally, the human factor cannot be ignored. Settlements are almost entirely contained on lower slopes with surficial cover, though in some regions terracing has made steep slopes habitable despite frequent local failures. Agricultural disturbance increases sediment yields by orders of magnitude (Montgomery 2007), particularly on the considerable slopes found in mountains.

\section{A general model of sediment yield for Canadian regions: scale effects}

All available specific sediment yield data for Canada were examined in order to assess spatial scale effects (Church et al. 1999). All parts of Canada from which monitored data were available were stratified according to hydroclimate, relief and typical land use disturbances. Seven distinct regions were identified: Atlantic coast, St. Lawrence Lowlands, southern Ontario, eastern Prairies, south Saskatchewan, Fraser-Columbia and the Peace-Mackenzie region (Fig. 8).

Scaling relations can be expressed in the form of a power law:

$$
\mathrm{L} / \mathrm{A}=\mathrm{kA}^{\mathrm{b}}
$$

where:

- L is the suspended sediment yield,

- A is the contributing basin area,

- $\quad b$ is the scale exponent that expresses the scale-related distortion of unit area yield and

- $\mathrm{k}$ is the true regional unit area yield. 


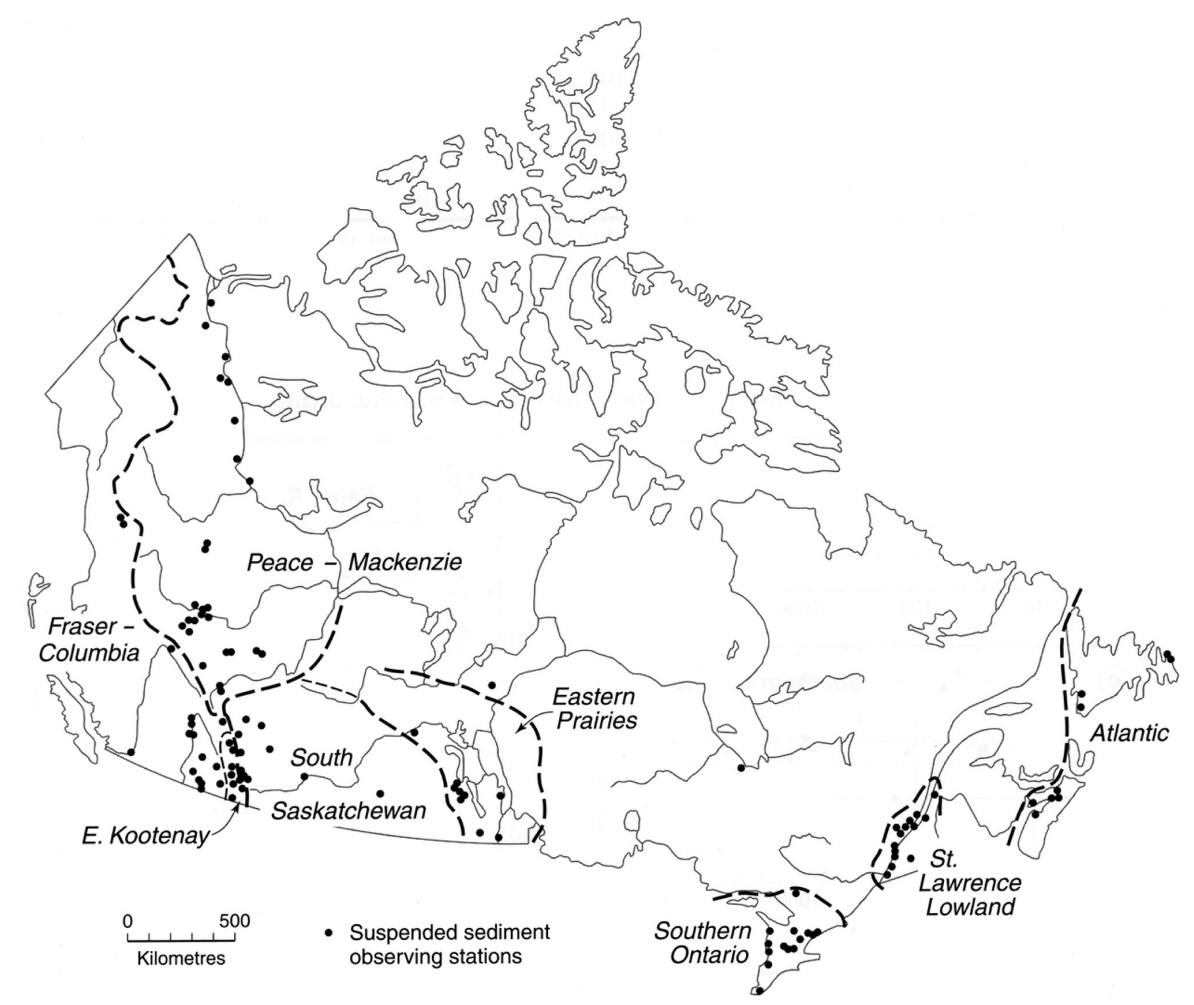

Fig. 8. Canadian suspended sediment yield regions identified by station clusters (Church et al. 1999)
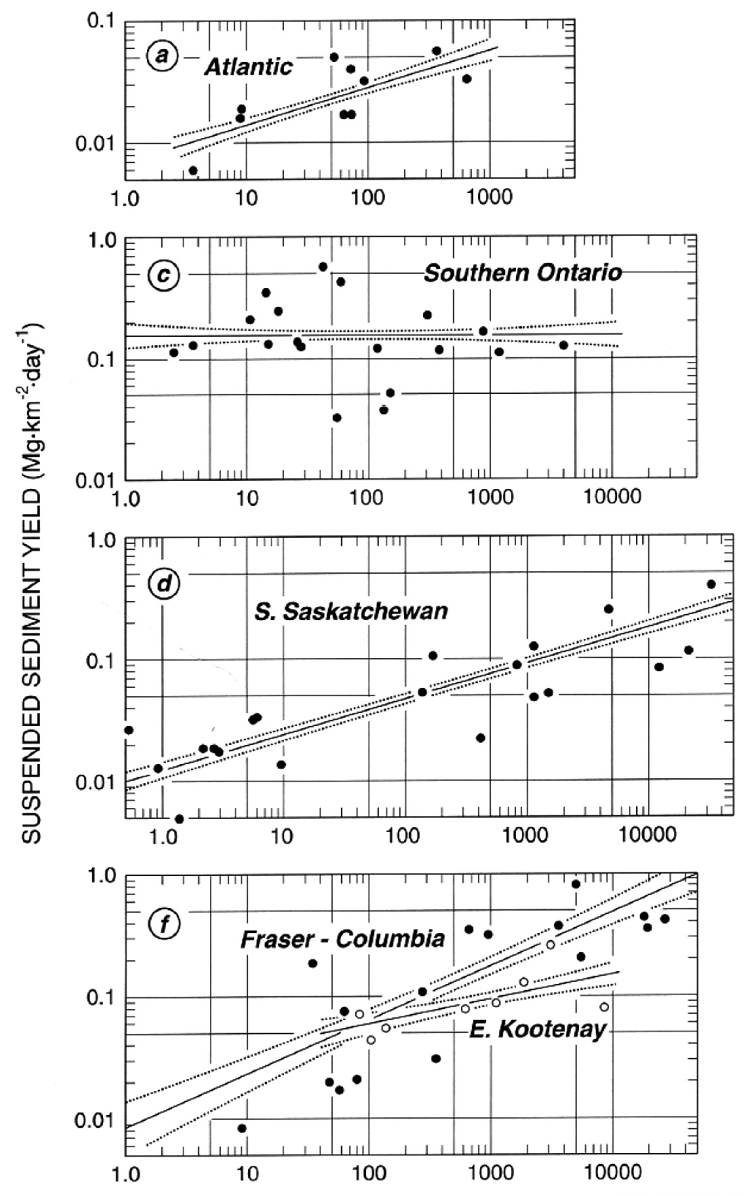
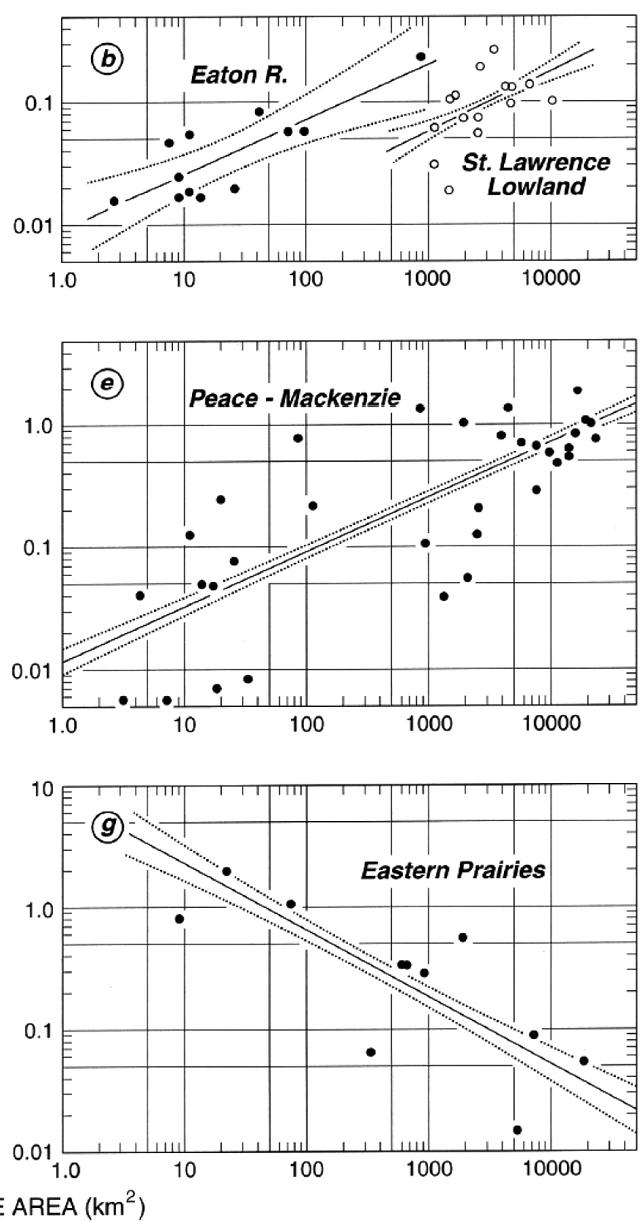

Fig. 9. Regional scale relations for fluvial suspended sediment yield (Church et al. 1999) 


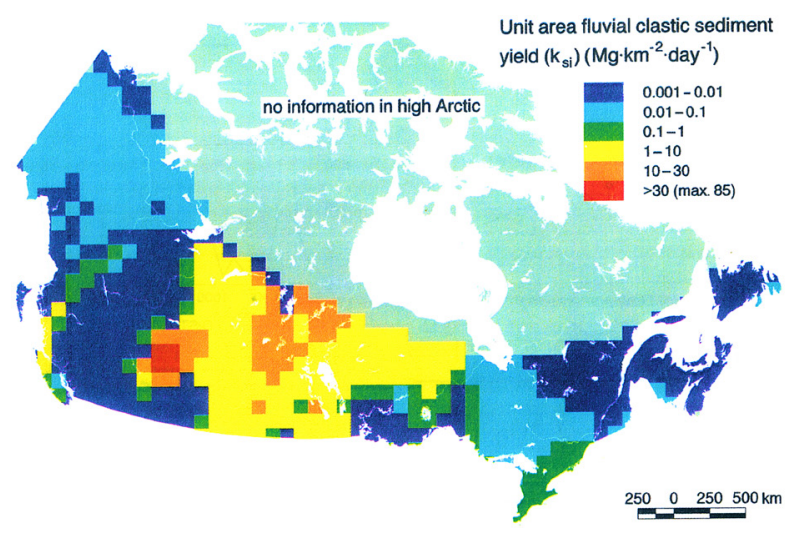

Fig. 10. Scaled unit area suspended fluvial sediment yield from undisturbed drainage basins in Canada (Church et al. 1999)

Despite significant scatter, the overall scale relation for all available data was highly significant: $b$ was +0.262 , which indicates a downstream increase in unit yield and downstream increase in total yield out of proportion to the contributing area increase.

Scale relations for each of the seven regions were calculated (Fig. 9). For five of the regions, b was positive; for southern Ontario b was essentially zero and for the eastern Prairies b was strongly negative. This implied that the first five regions showed a typical wildland signature with sediment yield declining downstream; southern Ontario, the most densely populated region in Canada, showed no trend and the eastern Prairies showed a typical aggrading river pattern, with sediment yield increasing downstream. Regional fluvial sediment yield showed a variable pattern indexed by the scale exponent $\mathrm{b}$. Where $\mathrm{b}$ is $<0$, there is systematic loss of sediment entrained from the land surface and channel aggradation; where $b$ is $>0$ there is recruitment of sediment along the channel and channel degradation. The uniform yield situation in southern Ontario is interpreted to mean that land use complexity masks the fluvial signal.

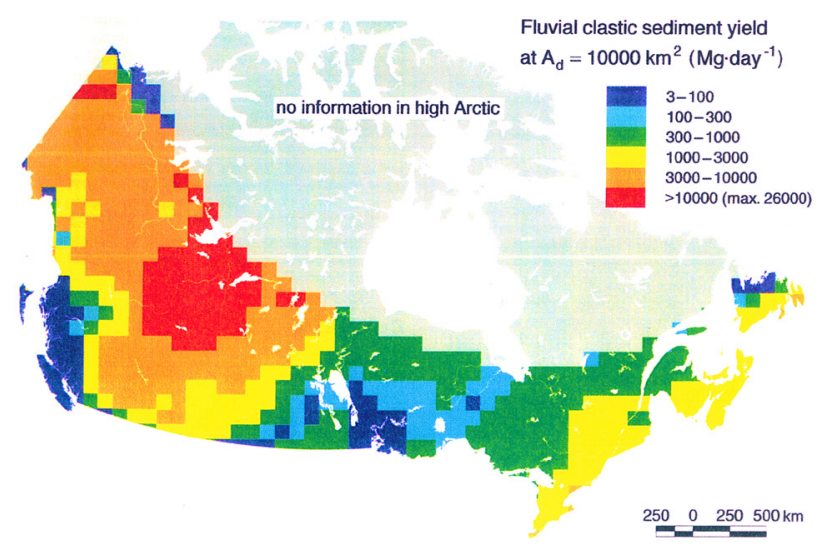

Fig. 11. Scaled suspended fluvial sediment yield from undisturbed drainage basins of reference area $10,000 \mathrm{~km}^{2}$ in Canada (Church et al. 1999)
The practical significance of these results is demonstrated in Figures 10 and 11, showing that regional patterns of specific sediment yield vary substantially depending on scale. The unit area fluvial clastic sediment yield (Fig. 10) showed generally high values in the Prairies and low values on east and west coasts. When only data from basins of order 10,000 $\mathrm{km}^{2}$ were used, the Western Cordillera became the dominant sediment contributor (Fig. 11).

\section{Specific sediment yield in the world's mountains}

\section{Glaciation}

High rates of denudation associated with glacierized basins, and the distinctive patterns of paraglacial sedimentation and erosion associated with formerly glaciated basins (Ballantyne 2002) suggest that denudation data from mountain regions should be classified into glacierized, glaciated and unglaciated mountains. The signature of glacial disturbance of a landscape is rather straightforward in terms of the distinctive landforms produced, both erosional and depositional. The assessment of the rate of that transformation, both in absolute terms and in terms relative to other agents of land transformation is more vexed. Many of the highest rates of monitored specific sediment yield in undisturbed mountains are

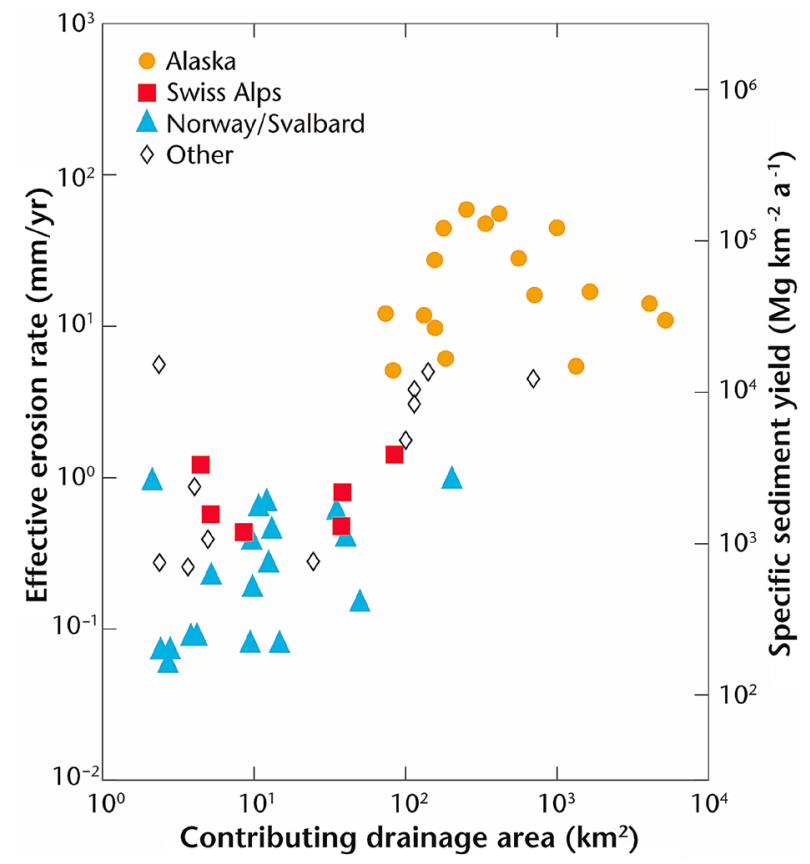

Fig. 12. Measured rates of specific sediment yield in glacierized mountains (Hallet et al. 1996)

Coloured symbols are measured rates of specific sediment yield in glacierized mountains; open symbols are extreme high mountain rates of sediment yield (Koppes, Montgomery 2009) 
found in glacierized southwest Alaska and Patagonia (Hallet et al. 1996, Koppes, Montgomery 2009). These are outputs from high to very high mountains and represent erosion rates of up to $100 \mathrm{~mm} \mathrm{a}^{-1}$ (Fig. 12). In the partially glacierized and strongly erodible Southern Alps of New Zealand $10-20 \mathrm{~mm} \mathrm{a}^{-1}$ denudation have been reported (Hicks et al. 1996). Large river basins achieve these higher rates as a consequence of an intensely active tectonic regime. Zones experiencing such high rates of erosion are relatively undisturbed by human settlement and are subject to the direct control of glaciers, geology and orogenic activity (as reflected in elevation and relief).

\section{A model of sediment yield for British Columbia}

An inverse relation between specific sediment yield and drainage basin area was almost universally reported before the 1980s. Colleagues have worked for thirty years to develop a summary of specific sediment yield in this mountainous province (Slaymaker 1987, Church et al. 1989, Church, Slaymaker 1989). Process domains are modified for glaciated mountains after a concept of Montgomery and Foufoula-Georgiou (1993). Figure 9 illustrates the increasing specific sediment yield with basin area in the fluvial cascade of British Columbia's mountains in the range of $1 \mathrm{~km}^{2}$ to $30,000 \mathrm{~km}^{2}$. But in basins $<1 \mathrm{~km}^{2}$ and $>30,000 \mathrm{~km}^{2}$ specific sediment yield decreases with basin size (Fig. 13). The alternating inverse and direct relations between specific sediment yield and basin size identified in the British Columbia model were the first exceptions to the traditional model. The relation was confirmed in a subsequent study (Ded-

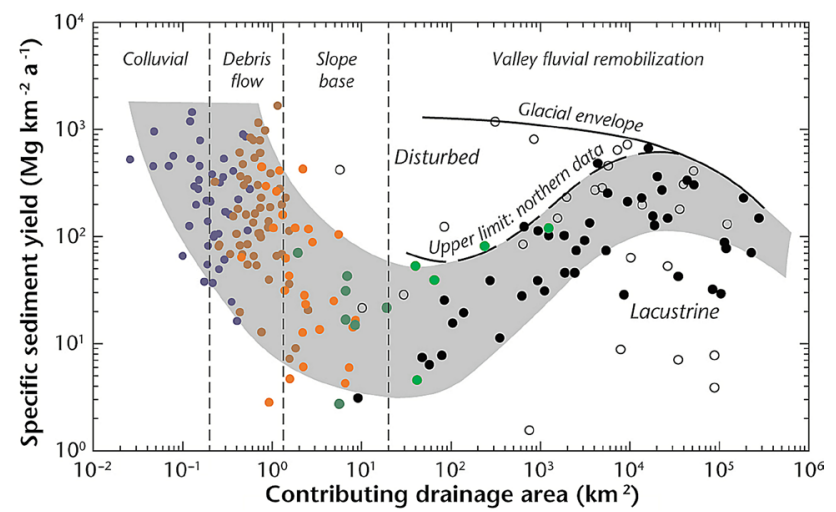

Fig. 13. Pattern of specific sediment yield in the glaciated Western Cordillera of British Columbia (Church, Slaymaker 2016)

Data up to $100 \mathrm{~km}^{2}$ are from numerous graduate student theses under the supervision of M.Church, O.Slaymaker and M. Hassan; dark blue spots are order 2 channels, brown - order 3, orange order 4, green - orders 5 and 6; data from larger areas (black spots and open circles) are from British Columbia gauging stations (Slaymaker 1987, Church, Slaymaker 1989); open symbols are disturbed or glacierized basins (upper values) or lacustrine sediment traps (lower values); process domains are modifications of a concept of Montgomery and Foufoula-Georgiou (1993).

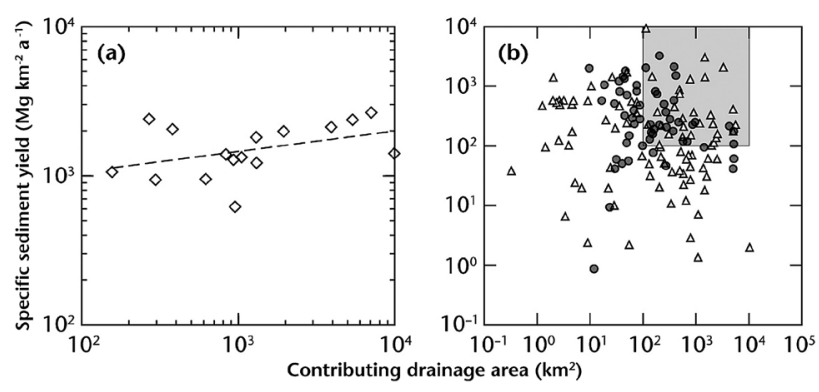

Fig. 14. Alpine specific sediment yield (a) over the Holocene Epoch from sediment volumes in Swiss alpine deltas (Hinderer 2001) and (b) massed data for the European Alps (after Vanmaercke et al. 2011)

Open circles are data derived from reservoirs; the shaded area in (b) represents the domain of (a).

kov, Mozherin 1992) which proposed that all data for Russia involved either direct scaling or inverse scaling relations in response to the relative importance of channel and slope erosion. Inverse relations could be anticipated where slope erosion is dominant, primarily in headwaters areas, and direct relations could be anticipated where channel erosion is dominant.

According to our model for British Columbia, there are at least three distinctive zones in every mountain basin, corresponding to distinct process zones. They can be characterized as:

- degrading hillslope zones,

- aggrading footslopes and valley sides, and

- channelized flows on valley floors demonstrating either net aggradation or degradation. These are identifiable repetitive elements in such landscapes and at local scale they have direct implications for human settlements, which are discussed below.

In the little disturbed landscape of British Columbia the evacuation of valley fill sediments involves largely glacial deposits. This pattern might be expected to be duplicated in the long term in all glaciated mountains, including ones subject to contemporary alpine glaciation. Indeed this is found to be the case for sediment yield over the Holocene epoch in the European Alps (Hinderer 2001) (Fig. 14a) but the relation is by no means universal (Fig. 14b).

\section{High and very high mountains $(>2,500 \mathrm{~m}$ a.s.l. and $>60 \mathrm{~m}$ of relief $\mathrm{km}^{-1}$ )}

The previous section has introduced a number of high mountain glacierized areas that display high specific sediment yields (Fig. 12). High and very high mountains that are glaciated but not glacierized are influenced by relief and lithology, as in volcanic mountains in the Philippines (Gran, Montgomery 2005).

The high mountains of Taiwan exhibit a crudely positive relation between specific sediment yield and area in conformity with the pattern of regional, river-driven degradation (Fig. 15). Despite heavy settle- 


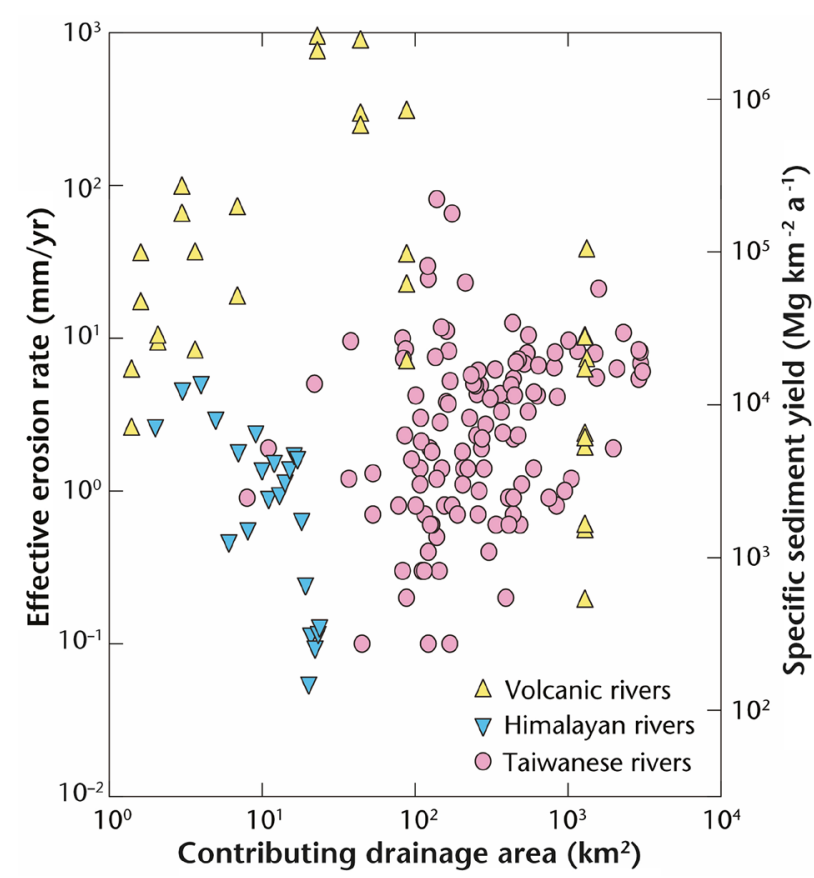

Fig. 15. Extreme high mountain rates of specific sediment yield in volcanic, Himalayan and Taiwanese rivers (Koppes and Montgomery, 2009) ment of the island, the major mountains remain relatively lightly settled because of the erosion hazards that high precipitation and high seismic risk present. Average rates of denudation around $5 \mathrm{~mm} \mathrm{a}^{-1}$ were early reported by Lin (1976). But geology is here an important additional factor as highly fractured mudstones in Taiwan have recorded specific sediment yields of close to $100 \mathrm{~mm} \mathrm{a}^{-1}$, of the same order as the most prolific glacierized basins (Dadson et al. 2003) (Fig. 15).

Lithology and high relief are also responsible for the disproportionate influence of the Carpathian Mountains on sediment supply to the Baltic Sea (Łajczak, Jansson 1993) (Fig. 16). The suspended sediment load derived from the source areas decreases during its transport to the Baltic but even so, the Vistula River provides $20 \%$ of the total suspended sediment supply to the Baltic Sea.

Decreasing specific sediment yield with increasing area, denoting hillslope erosion and aggradation along the trunk valleys, is evident in the one million $\mathrm{km}^{2}$ Madeira (Beni) basin of Bolivia-Brazil (Guyot et al. 1996). This river basin exhibits declining specific sediment yield with increasing area at scales beyond
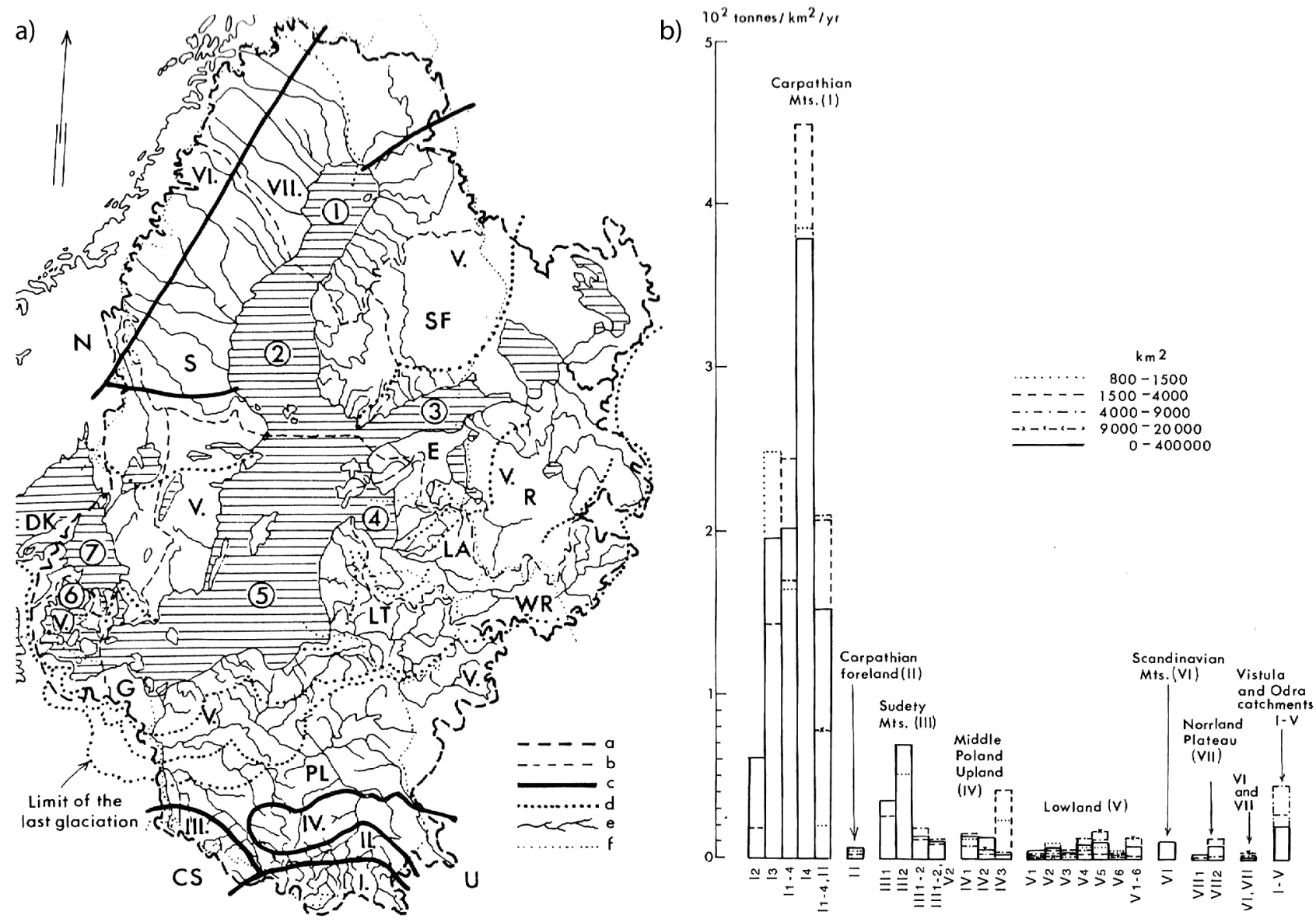

Fig. 16. The Baltic Sea drainage basin and major relief units (Łajczak, Jansson 1993)

a) I - Carpathian Mountains, II - Carpathian Foreland, III - Sudety Mountains, IV - Middle Polish Upland, V - Lowland area, VI - Scandinavian Mountains, VII - Norrland Plateau, b) suspended sediment yield of Baltic Sea tributaries 


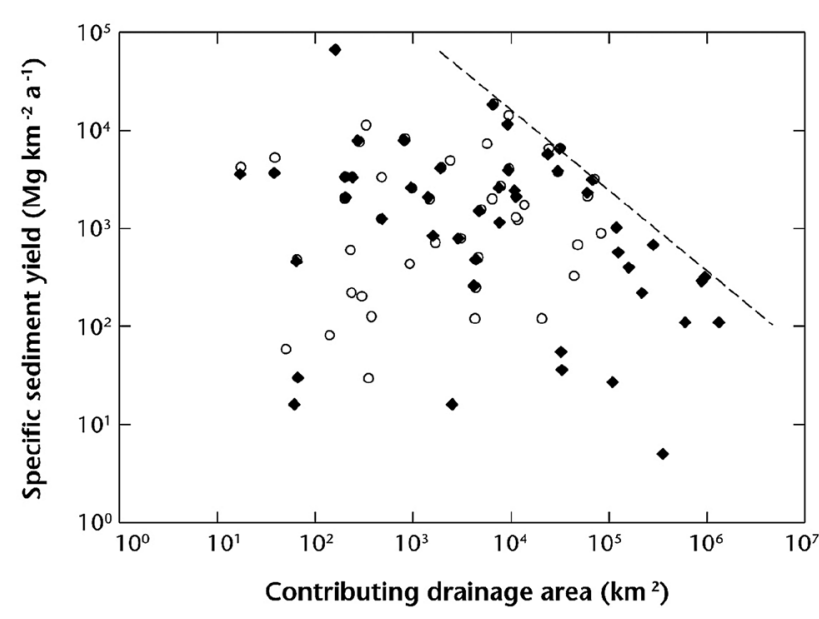

Fig. 17. Specific sediment yield in the Madeira (Beni) basin of Bolivia-Brazil

Black symbols are data from Guyot et al. 1996) and open symbols are the data of Aalto et al (2006) from the eastern Andes that show no trend; geology and relief explain $90 \%$ of the variation in specific sediment yield within the Bolivian steeplands

$10,000 \mathrm{~km}^{2}$ as the rivers flow into the Andean foreland basin of western Brazil (Fig. 17). By contrast, the steeplands of the eastern Andes in Bolivia showed no trend in specific sediment yield in drainage basins varying in area from $17 \mathrm{~km}^{2}$ to $81,000 \mathrm{~km}^{2}$ (Aalto et al. 2006) (Fig. 17). The region is entirely steepland precluding significant sediment storage along river channels. Ninety percent of the variation in sediment yield is accounted for by lithology and topographic gradient.

\section{Mid-elevation and low mountains (500-2,500 $\mathrm{m}$ a.s.l. and $>60 \mathrm{~m}$ of relief $\mathrm{km}^{-1}$ )}

Eighty eight percent of the world's mountain population lives in this mid-elevation to low mountain zone. When human activity is superimposed on these mountain environments, specific sediment yields can

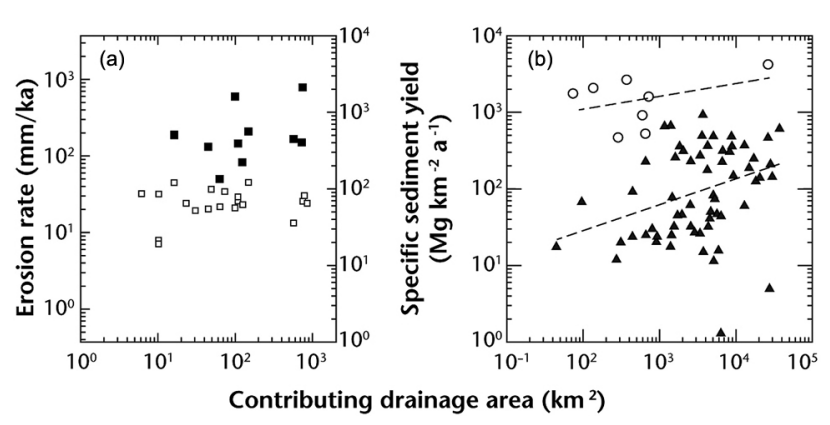

Fig. 18. Relation between specific sediment yield and drainage area

a) black symbols are for Sri Lankan uplands using black symbols; open symbols are for soil production rates are also shown (after Hewawasam et al. 2003), b) black triangles are for specific sediment yield in the Anatolian plateau (after Vanmaercke et al. 2011) with open symbols representing data derived from reservoirs increase by several orders of magnitude over natural rates of soil production and erosion (Montgomery 2007, Slaymaker 2010, 2013). An interesting example is found in the monsoon tropical central uplands of Sri Lanka (Hewawasam et al. 2003) where the mountains reach 2,535 $\mathrm{m}$ a.s.l. Specific sediment yield varies directly with drainage area at scales out to at least $1,000 \mathrm{~km}^{2}$ while primary erosion measured by cosmogenic nuclides is one order of magnitude smaller and shows no scale dependency (Fig. 18a). This indicates increasing sediment removal down-gradient, representing either increasingly severe land erosion or significant river degradation. There is no sediment storage in this intermediate mountain zone, up to a scale of $10^{3} \mathrm{~km}^{2}$. The Sri Lankan upland soil is being lost 10-100 times faster from agriculture than it is being produced.

The Anatolian Plateau is an arid region of mid-elevation mountains beyond glacial influence that present a strong climatic contrast with tropical mountains. Yet it similarly presents a raggedly positive relation between specific sediment yield and area out to about 50,000 $\mathrm{km}^{2}$ (Fig. 18b) (Vanmaercke et al. 2011).

Norwegian data (Bogen 1996) display the traditional inverse relation between specific sediment yield and drainage area (Fig. 19) implying loss to storage of sediments mobilized in the uplands. That portion of the Norwegian landscape that is represented by available measurements indicates glacially conditioned aggradation in downstream valleys. However, the largest drainage basin in Norway $\left(43,000 \mathrm{~km}^{2}\right)$ has large accessible sources of glacimarine sediments in its lower reaches. Whereas specific sediment yield declines with basin area in the upper basin, it increases in the lower basin (Fig. 19). Similar specific sediment yield signatures responding to the presence of glacimarine sediments below the marine limit are also seen in the Trondheim region of central Norway (Bogen, Bønsnes 2004). They provide guidance on the importance of

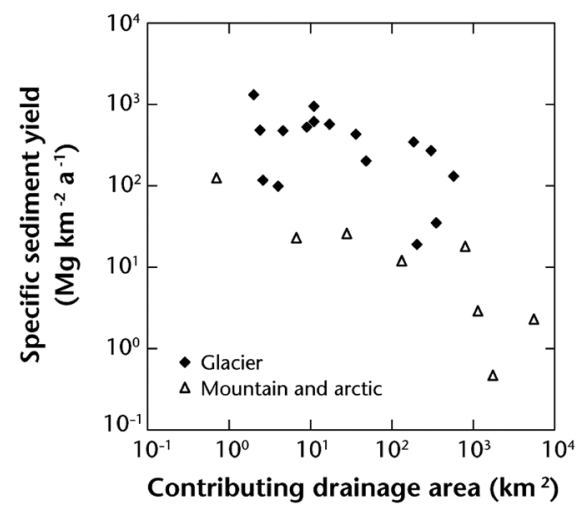

Fig. 19. Specific sediment yield in Norway showing both contemporary glacierized catchments (black symbols) and formerly glaciated basins (open symbols); data from Bogen (1996) (Church, Slaymaker 2016) 
separating out the disturbance regime landscape elements: whether the disturbance is on the valley bottom or at mid-slope and what the specific land use activities are that are most destructive.

\section{Mountain sediment yields and human settlement}

\section{General principles}

Land use influences sediment yield and sediment storage in the world's mountain regions in two contrasting ways. In mature human landscapes deliberate land use treatments have been applied with the purpose of stabilizing the mountain landscape whereas in less developed countries where mountain populations are growing most rapidly, it is almost impossible to control sediment yield. Process domains, identified in Fig. 13 for glaciated British Columbia, are repeated here in order to demonstrate their potential implications for mountain sediment yields and human settlements globally.

\section{The hillslope zone}

The hillslope zone is characterized by rapid, large and frequent mass wasting events (e.g. Hewitt, 2006), which pose a significant hazard to settlements, largely occurring in narrow valleys below steep slopes. This is the zone with the maximum, but also the most variable sediment yield as a function of geology, relief and elevation.

The footslope and valley zone

The footslope and valley zone coincides with the areas of the mountains that are most intensively cultivated. This zone is therefore vulnerable because there is a ready supply of sediment from upslope and land use activities produce accelerated sediment yield. This is commonly a zone of sediment accumulation from hillslopes above, but also the zone with maximum sediment yield associated with land use change.

\section{Channelized flows on valley floors}

The outlets of headward mountain basins commonly coincide with a significant change of gradient. If the mountain system is degrading, specific sediment yield will achieve maximum values where sediment begins to be deposited at the change of gradient. Aggradation of colluvial or alluvial fans will occur in the transition zone from mountain to lowland, and sediment yield will decline downstream. The hazard for settlement is obvious, but the sites are also attractive as the only ground suitable for settlement and cultivation. Aggrading braided channel systems will pose a hazard arising from channel instability and flood hazards in broader valley bottoms where alluvial soils are intensively cultivated. But conversely, actively degrading channels may pose significant bank erosion problems as well.

\section{Mid-elevation mountain regions in Austria and Ethiopia compared}

Contrasting examples of land management effects on sedimentation and erosion in mid-elevation mountain regions are available from both Austria and Ethiopia (Slaymaker, Embleton-Hamann 2009).

\section{Austrian Alps}

In the Austrian Alps, where population density is around $50 \mathrm{~km}^{-2}$, the majority live in the valley bot-

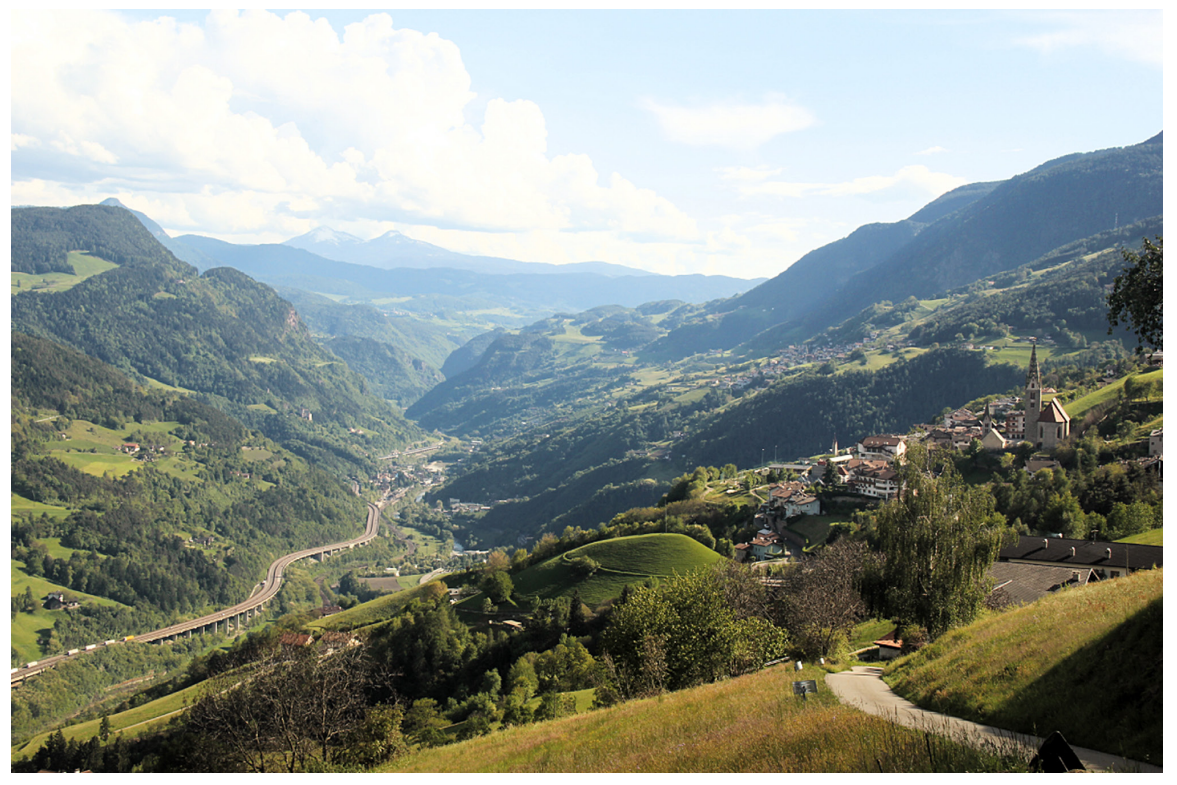

Fig. 20. Narrow valley below steep slopes in temperate alpine zone utilized as transport corridor in the Eisack Valley, village of Villanders in the foreground, southern Tyrol, Austria (photo by Herbert Baumhackl) 
toms below 1,000 $\mathrm{m}$ a.s.l. though the mountains themselves are largely mid-elevation mountains (Fig. 20). The human landscape is a mature product of at least one thousand years of evolution. Recent net afforestation, expansion of protected areas and reduced intensity of forest harvesting are land use treatments that reduce erosion in the mountain landscape. Reduced risk of flooding, erosion and snow avalanche incidence is provided for the residential areas in the valleys by sophisticated torrent control service (Slaymaker, Embleton-Hamann 2009). Specific sediment yield is further controlled by hydroelectric power production dams and torrent control channels which provide a modest absolute specific sediment yield and a scale-free effect. Figure $14 \mathrm{~b}$, which compiles data from the larger alpine region illustrates the lack of strongly defined scaling in the region. Debris flow activity, by contrast with fluvial suspended sediment transport, demonstrates an inverse relation between specific sediment yield and basin area. Brardinoni et al. (2012) have demonstrated a similar inverse scaling that is strongly lithologically conditioned between specific sediment yield and area in hillslope debris flow-dominated small drainage basins in the South Tyrol (Alto Adige region) of the Italian Alps.

\section{Ethiopian Highlands}

In the Ethiopian Highlands, where current population density is around $80 \mathrm{~km}^{-2}$ and is rapidly increasing, the inhabitants are concentrated in mid-elevation mountains (Fig. 21). Given that the intensive land use, especially agricultural and road building, is concentrated in the upper parts of the river basins, one would anticipate that specific sediment yield rates would be high and that the signature would be one of maximum rates in the upper parts of the basins, rapidly declining down valley. A lively debate between Nyssen et al. (2004) and Hurni et al. (2005) has emphasized two different aspects of the situation. The former have shown that slope erosion at the upper ends of the Ethiopian basins has declined over the past thirty years as a result of careful slope erosion control, whereas the latter, using stream sediment data, have insisted that intensified land use and land degradation induced by population increase have increased surface runoff and specific sediment yield in the headwaters of the Blue Nile and Tekle rivers. The probable explanation for these apparently contradictory results lies partly in the different parts of the Ethiopian Highlands studied, but also more interestingly in the present perspective, in the lagged effects of changing land use practices. Slopes have been decoupled from the fluvial system in one area, as described by Nyssen et al. (2004), whilst the signal of proximal degradation continues to propagate through the more extended landscape in the other (Hurni et al. 2005). In the context of the Himalayas, Hewitt (2006) has discussed and illustrated what he calls disturbance regime landscapes resulting from the interruption of mountain drainage systems by large rock slides. In the present discussion, the accelerating population density and associated intensified land use represents an analogous disturbance regime landscape.

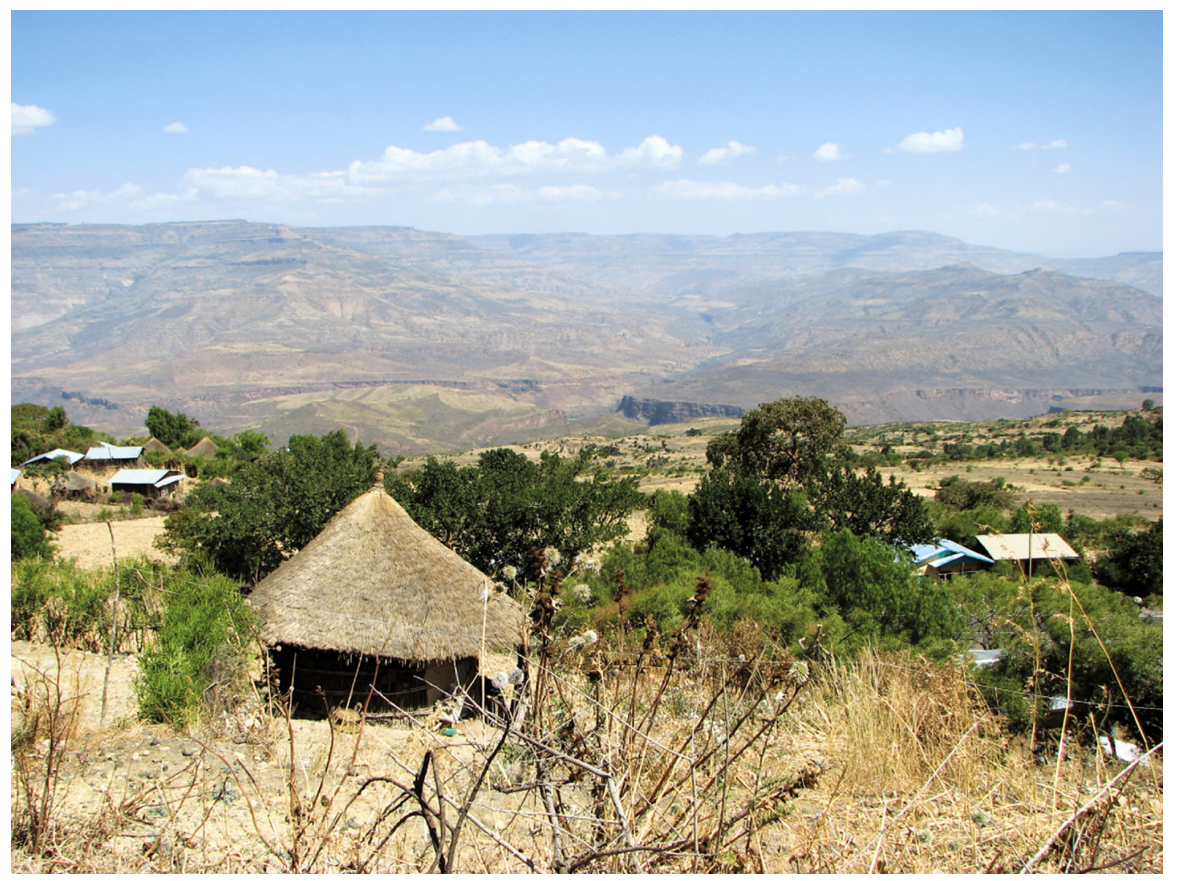

Fig. 21. Intertropical montane zone tending to exceed ecological carrying capacity, village of Arba Minch, Southern Nations, Nationalities and People's Region, Ethiopia. View toward the east across the East African Rift Valley to the Southern Ethiopian Highlands (photo by Herbert Baumhackl) 


\section{Conclusions}

The pattern of denudation, to the extent that it is measured by sediment flux versus river basin area relationships, differs widely as a function of scale, relief, lithology and disturbance types and location within each basin. Disturbance types include the presence of glaciers, land use activities of various types and potentially hydroclimate change. In this study we have confined ourselves to mountain regions, stratified by spatial scale, glacier presence or absence, relief, and degree and type of human disturbance.

A general model of scalar relations of specific sediment yield for Canadian regions demonstrates that specific sediment yield data should only be compared if scaled to contributing area. A regional summary of specific sediment yield in mountainous British Columbia confirms that in mountain basins $<1 \mathrm{~km}^{2}$ and $>30,000 \mathrm{~km}^{2}$ specific sediment yield decreases with basin size whereas in basins of intermediate size specific sediment yield increases with basin size. This effect is interpreted in terms of three distinct process zones of sediment mobilization or deposition in every mountain basin. These are identifiable repeating elements in such landscapes. Suspended sediment yield data from mountainous regions around the world are considered in light of the British Columbia model. Some support for the model is found where basins are stratified according to scale, relief, lithology and disturbance types and location within each basin are considered. Disturbance types include the presence of glaciers, land use activities of various kinds, such as increasing population pressure in the intertropical montane zone, changing population distribution and associated economic activities in the temperate montane zone, and potentially hydroclimate change. Different kinds of disturbance, both natural and societally induced, and different disturbance locations within a basin produce different patterns.

\section{Acknowledgment}

I acknowledge that many of the ideas contained in this paper result from collaboration with my colleague, Mike Church. I also acknowledge the contributions of many of our graduate students to the data points in Figure 13. My thanks also to Adam Lajczak for drawing my attention to his work which is consistent with many of the findings from our Canadian work. The cartography was provided by Eric Leinberger. Two anonymous reviewers did a remarkable job of cleaning up the text, with thanks.

\section{References}

Aalto R., Dunne T., Guyot J.L., 2006. Geomorphic controls on Andean denudation rates. Journal of Geology 114: 85-99.

Ahnert F., 1970. Functional relationships between denudation, relief and uplift in large mid-latitude drainage basins. American Journal of Science 268: 243-263.

Ahnert F., 1987. Process-response models of denudation at different spatial scales. Catena Supp. 10: 31-50.

Ballantyne C., 2002. Paraglacial geomorphology. Quaternary Science Reviews 21: 1935-2017.

Beylich A., 2000. Geomorphology, sediment budget, and relief development in Austdalur, Austfirdir, East Iceland. Arctic, Antarctic and Alpine Research 32: 466-467.

Beylich A., 2011. Mass transfers, sediment budgets and relief development in cold environments: results of long-term geomorphologic drainage basin studies in Iceland, Swedish Lapland and Finnish Lapland. Zeitschrift für Geomorphologie 55: 145-174.

Bogen J., 1996. Erosion and sediment yield in Norwegian rivers. In: D.E.Walling, B.W.Webb (eds.), Erosion and Sediment Yield: Global and Regional Perspectives. International Association of Hydrological Sciences Special Publication 236: 73-84.

Bogen J., Bønsnes T.E., 2004. The impact of erosion protection work on sediment transport in River Gråelva, Norway. In: V.Golosov, V.Belyaev, D.E.Walling (eds.), Sediment Transport Through the Fluvial System. International Association of Hydrological Sciences Special Publication 288: 155-164.

Brardinoni F., Church M., Simoni A., Macconi P., 2012. Lithologic and glacially conditioned controls on regional debris flow dynamics. Geology 40: 455-458.

Church M., Ham D., Hassan M., Slaymaker O., 1999. Fluvial clastic sediment yield in Canada: a scaled analysis. Canadian Journal of Earth Sciences 36: 1267-1280.

Church M., Slaymaker O., 1989. Holocene disequilibrium of sediment yield in glaciated British Columbia. Nature 337: 452-454.

Church M., Slaymaker O., 2016. Signatures of sediment yield in the world's mountains. In: K.Mainali, S.Sicroff (eds.), Jack D. Ives, Montologist: Festschrift for a Mountain Advocate. Himalayan Association for the Advancement of Science, Lalitpur, Nepal: 67-93.

Dadson S.J., Hovius N., Chen H., Dade W.B., Hsieh M-C., Willett S.D., Hu J-C., Horng M-J., Chen M-C., Stark C.P., Lague D., Lin J-C., 2003. Links between erosion, runoff variability and seismicity in the Taiwan orogeny. Nature 426: 648-651.

Dedkov A.P., Mozherin V.T., 1992. Erosion and sediment yield in mountain areas of the world. In: D.E.Walling, T.R.Davies, B.Hasholt (eds.), Erosion, Debris Flows and Environment in Mountain Regions. International Association of Hydrological Sciences Special Publication 209: 29-36.

Gran K.B., Montgomery D.R., 2005. Spatial and temporal patterns in fluvial recovery following volcanic eruptions: channel response to basin-wide sediment loading at Mount Pinatubo, Philippines. Geological Society of America Bulletin 117: 195211.

Guyot J.L., Filizola N., Quintanilla J., Cortez J., 1996. Dissolved solids and suspended sediment in the Rio Madeira basin, from the Bolivian Andes to the Amazon. In: D.E.Walling, B.W.Webb (eds.), Erosion and Sediment Yield: Global and Regional Perspectives. International Association of Hydrological Sciences Special Publication 236: 55-63.

Hallet B., Hunter L., Bogen J., 1996. Rates of erosion and sediment evacuation by glaciers: a review of field data and their implications. Global and Planetary Change 12: 213-235.

Hewawasam T., von Blankenburg F., Schaller M., Kubik P., 2003. Increase of human over natural erosion rates in tropical highlands constrained by cosmogenic nuclides. Geology 31: 597-600. 
Hewitt K., 2006. Disturbance regime landscapes: mountain drainage systems interrupted by large rock slides. Progress in Physical Geography 30: 365-393.

Hicks D.M., Hill J., Shankar U., 1996. Variation of suspended sediment yields around New Zealand: the relative importance of rainfall and geology. In: D.E.Walling, B.W.Webb (eds.), Erosion and Sediment Yield: Global and Regional Perspectives. International Association of Hydrological Sciences Special Publication 236: 149-156.

Hinderer M., 2001. Late Quaternary denudation of the Alps, valley and lake fillings and modern river loads. Geodinamica Acta 14: 231-263.

Hurni H., Tato K., Zeleke G., 2005. The implications of changes in population, land use and land management for surface runoff in the upper Nile basin in Ethiopia. Mountain Research and Development 25: 147-154.

Koppes M.N., Montgomery D.R., 2009. The relative efficacy of fluvial and glacial erosion over modern to orogenic time scales. Nature Geoscience 2: 644-647.

Łajczak A., Jansson M.B.,1993. Suspended sediment yield in the Baltic drainage basin. Nordic Hydrology 24: 31-52.

Lin Y.H., 1976. Denudation of Taiwan Island since the Pliocene Epoch. Geology 4: 105-107.

Meybeck M., 1979. Concentration des eaux fluviales en éléments majeurs et apports en solution aux oceans. Revue de Géologie Dynamique et Géographie Physique 21: 215-246.

Meybeck M., 1982. Carbon, nitrogen and phosphorous transport by world rivers. American Journal of Science 282: 401-450.

Meybeck M., 2003. Global analysis of river systems: from Earth system controls to Anthropocene syndromes. Philosophical Transactions of the Royal Society of London B 358: 1935-1955.
Montgomery D.R., 2007. Soil erosion and agricultural sustainability. Proceedings of the National Academy of Sciences (USA) 104: 13,268-13,272.

Montgomery D.R., Foufoula-Georgiou E., 1993. Channel network source representation using digital elevation models. Water Resources Research 29: 3925-3934.

Nyssen J., Poesen J., Moeyersons J., Deckers J., Haile M., Lang A., 2004. Human impact on the environment in the Ethiopian and Eritrean Highlands: a state of the art. Earth Science Reviews 64: 273-320.

Slaymaker H.O., 1968. Patterns of erosion in instrumented catchments. Unpublished Ph.D. Thesis, University of Cambridge.

Slaymaker O., 1972. Patterns of present subaerial erosion and landforms in mid-Wales. Transactions of the Institute of British Geographers 55: 47-68.

Slaymaker O., 1987. Sediment and solute yields in BC and Yukon: their geomorphic significance reexamined. In: V.Gardiner (ed.), International Geomorphology, Volume 1. John Wiley and Sons, Chichester: 925-945.

Slaymaker O., 2010. Drivers of mountain landscape change during the twenty-first century. Journal of Soils and Sediments 10: 597-610.

Slaymaker O., 2013. Mountain environment changes in the Anthropocene epoch. Opera Corcontica 50: 107-118.

Slaymaker O., Embleton-Hamann C., 2009. Mountains. In: O.Slaymaker, T.Spencer, C.Embleton-Hamann (eds.), Geomorphology and Global Environmental Change. Cambridge University Press, Cambridge: 37-70.

Vanmaercke M., Poesen J., Verstraeten G., de Vente J., Ocakoglu F., 2011. Sediment yield in Europe: spatial patterns and scale dependency. Geomorphology 130: 142-161. 